\title{
Changes in foliar nutrient content and resorption in Fraxinus excelsior L., Ulmus minor Mill. and Clematis vitalba $\mathbf{L}$. after prevention of floods
}

\author{
Michèle Trémolières ${ }^{\mathrm{a}^{*}}$, Annik Schnitzler ${ }^{\mathrm{b}}$, José-Miguel Sánchez-Pérez ${ }^{\mathrm{c}}$, Diane Schmitt ${ }^{\mathrm{a}}$ \\ ${ }^{a}$ Laboratoire de botanique et d'écologie végétale, CEREG CNRS/ULP, Institut de botanique, \\ 28 , rue Goethe, 67083 Strasbourg, France \\ ${ }^{b}$ Laboratoire de phytoécologie, Université de Metz, Ile du Saulcy, 57045 Metz, France \\ 'Centre d'études et de recherches éco-géographiques, CEREG CNRS/ULP, 3, rue de l'Argonne, 67083 Strasbourg, France
}

(Received 24 December 1998; accepted 11 March 1999)

\begin{abstract}
This paper focuses on the impact of flood on tree mineral nutrition through measurement of resorption (i.e. transfer of nutrients from leaves to perennial organs). Nutrient ( $\mathrm{N}, \mathrm{P}, \mathrm{K}, \mathrm{Mg}, \mathrm{Ca})$ concentrations in leaves of three representative species, Fraxinus excelsior L., Ulmus minor Mill. and Clematis vitalba L. were measured before and after abscission on flooded and unflooded hardwood forests of the upper Rhine plain. The nutrient concentrations in the soils, which were measured in the top layer of the study sites, were higher in the flooded sites for $\mathrm{P}$ but slightly lower for $\mathrm{N}$ and $\mathrm{K}$, and identical at both types of site for Ca and $\mathrm{Mg}$. The summer foliage concentrations were higher for $\mathrm{N}$ and $\mathrm{P}$ in the flooded areas, and probably related to the flooding process, which contributes to regular nutrient inputs in the flooded forest, causes high fluctuations of water level and increases bioavailability of certain nutrients. Resorption occurred for all nutrients in the three species, and was higher for $\mathrm{N}, \mathrm{P}$ and $\mathrm{K}(40-70 \%)$ than for $\mathrm{Ca}$ and $\mathrm{Mg}$ $(0-45 \%)$, but not significantly different at the two sites. This paper stresses the variability of the test species response (nutrient content and resorption) to the soil and flood water nutrient sources, and tries to specify parameters which control resorption, i.e. soil fertility, tree species or flood stress. C 1999 Inra/Éditions scientifiques et médicales Elsevier SAS.
\end{abstract}

nutrient / resorption/ floods / alluvial forest / mineral nutrition / ligneous species

Résumé - Impact de la suppression des inondations sur le contenu minéral foliaire et la retranslocation chez Fraxinus exelsior, Ulmus minor et Clematis vitalba. Afin de vérifier l'influence des crues sur la nutrition minérale d'espèces ligneuses en zone alluviale, nous avons étudié le transfert des nutriments des feuilles vers les organes pérennes à la sénescence (résorption). Les concentrations de nutriments (N, P, K, Mg, Ca) ont été mesurées dans les feuilles de trois espèces ligneuses, Fraxinus excelsior L., Ulmus minor Mill. et Clematis vitalba $\mathrm{L}$. avant et après abscission dans des forêts alluviales inondables et non inondables de la plaine du Rhin supérieur. Alors que les concentrations de phosphore dans l'horizon superficiel des sols inondables sont plus élevées que celles mesurées dans les sols non inondés, elles sont un peu plus faibles pour l'azote et le potassium et identiques pour Ca et $\mathrm{Mg}$ entre les deux types de sites. Les concentrations d'azote et de phosphore dans les feuilles d'été sont en général plus élevées dans les sites inondables. Ce résultat est à mettre en relation avec les inondations qui apportent des nutriments, provoquent des fluctuations importantes des niveaux d'eau et augmentent la biodisponibilité de certains nutriments. On mesure une résorption de tous les nutriments pour les trois espèces non significativement différente entre les deux types de sites; elle est cependant plus importante pour $\mathrm{N}$, $\mathrm{P}, \mathrm{K}(40-70 \%)$ que pour $\mathrm{Ca}$ et $\mathrm{Mg}(0-45 \%)$. Le contenu foliaire et la résorption des nutriments sont analysés comme éléments de réponse des espèces tests aux paramètres de contrôle: la fertilité des sols et les inondations. (C) 1999 Inra/Éditions scientifiques et médicales Elsevier SAS.

nutriment / résorption / forêt alluviale / nutrition minérale / espèce ligneuse

\footnotetext{
* Correspondence and reprints

tremolieres@geographie.u-strasgb.fr
} 


\section{Introduction}

Nutrient resorption is known as one of the most important of all strategies employed by plants to economize nutrients before senescing. Soil fertility is often considered as a main factor in controlling resorption. However, the relationship between resorption and soil fertility is a controversy with a long history: some studies have shown that resorption may increase with rising nutrient availability $[13,27,28,32,39]$, others that there is a decrease with increase in soil nutrient content $[5,11]$ and in other cases, resorption efficiency is not influenced by soil conditions $[1,4,16]$ suggesting that other parameters can influence resorption. In alluvial forests, regularly flooded sites offer the best conditions for plant nutrition, particularly when the flood waters are nutrientrich and the soils not too reducing to lead to a removal of nitrogen by denitrification, for example $[9,20,22,42$, 43 ]. When flooding is prevented by a dyke or canal construction, N/P ratios in litter increase after a few years $[24,35,43]$. These latter authors suggested that fluctuations in soil nutrient availability after elimination of floods may have caused enhancement of nutrient resorption from tree foliage back to woody tissues in the autumn. Similar conclusions were published for the forests of the Amazon: where floodplain soils were relatively poor in nutrients as in the igapo forests, nutrient resorption from leaves prior to abscission may be important in the conservation of elements [20].

In the light of these contradictory results, we propose a study which investigates the relative significance of nutrient resorption in three deciduous woody species in relation to the suppression of floods in the upper Rhine valley (France). We wish to answer the question: what is the consequence of fluctuations in soil nutrient and water on the mineral nutrition of trees since the floods of which the unflooded site is deprived, which contribute to the inputs of nutrients and to high variations in groundwater level, in the alluvial forest ecosystem? Floods could also have a stress effect on some species by their impact on oxygenation of soil (root asphyxia). Moreover, Aerts [1] suggests that the resorption process could be linked to soil moisture availability or shoot production ('sink strength') and the rate of phloem transport (source-sink interactions), depending, however, on the species (e.g. structure or leaf longevity [38], and the resorbed element [11].

\section{Study area}

\subsection{Site description}

The upper Rhine valley in the north-eastern region of Alsace, France, includes extensive forested wetlands, naturally flooded prior to 1850 . Since then, river management has increasingly reduced flood frequency, duration and height. About 4000 ha of wetlands have thus been unflooded since the building of dykes in 1850, and flooded areas are now reduced to small islands of a few hectares [40]. Rhine floods occur mostly in the summer.

Soils (fluvent A/C type, USDA) of flooded and unflooded areas are young, coarse-textured and calcareous [34] On the islands, floods deposit a nutrient-rich layer of silt every 2 or 3 years.

\subsection{Experimental stands}

Three stands at a distance of $20 \mathrm{~km}$ from each other were chosen in the flooded island forests, as well as three other comparable stands in unflooded areas behind the dykes. All have retained a semi-natural structure owing to relatively limited human management.

Sites were selected to be as homogeneous as possible with respect to soil type, generally with a silty top layer $1.5 \mathrm{~m}$ thick, $20 \%$ clay in the superficial layer and a pH above 7.5. In order to standardize the influence of forest structure and stand age on the behaviour of the selected woody species as far as possible, similar hardwood communities near equilibrium (100-150 years old) were selected, with a characteristic canopy composed of three tree species (Fraxinus excelsior L., Quercus robur L., Ulmus minor Mill.) and two arboreal lianas (Hedera helix L. and Clematis vitalba L.).

The test species were canopy species (Fraxinus excelsior, Ulmus minor and Clematis vitalba). Choice of these particular species was guided by changes recorded in growth and pattern after elimination of flood risk [36, 37].

\section{Materials and methods}

\subsection{Soil sampling and analysis}

Since nutrients are concentrated mainly in the topsoil [34], we sampled only the upper $15 \mathrm{~cm}$ of the A1 horizon. One soil sample per site, consisting of ten cylindrical subsamples, was taken. The soil was dried at $105^{\circ} \mathrm{C}$ for $48 \mathrm{~h}$ and sieved $(<2 \mathrm{~mm})$. Organic carbon was measured by the Anne method. Total nitrogen was measured by the Kjeldahl method (after digestion with sulphuric acid at $350^{\circ} \mathrm{C}$ ). Exchangeable cations $(\mathrm{Ca}, \mathrm{Mg}, \mathrm{K})$ were extracted with $1 \mathrm{~N}$ ammonium acetate at $\mathrm{pH} 7$ and analysed by flame AAS. Available phosphorus was assessed by extraction with $0.2 \mathrm{~N}$ ammonium oxalate 
following the Joret-Hébert method for calcareous soils [34].

\subsection{Leaf sampling}

We collected shade leaves, which we consider as representative of the understory stratum, $1-3 \mathrm{~m}$ above ground in summer and autumn 1990. In fact, in a study in progress we have measured no significant difference in nutrient leaching between low and high levels of the canopy for an understory tree, as also shown by Son and Gower [38] for evergreen species. Three individuals for each species were selected per site. Three flooded sites and three unflooded sites were sampled.

Three pairs of leaves per individual tree or liana, as similar in size, shape and shoot location as possible, were selected for study when mature (August). Leaflets were used for Fraxinus excelsior. All areas of the laminae of each of the three test species were photographed with a reference grid, and areas determined with a leaf area meter (Delta T device Ltd, Burwell). Then, half the leaves (one of each pair) were collected. The remaining leaf of each pair was attached to parent stems with a thread using a sewing needle so as to be able to recover them after natural abscission. Senescent leaves were collected between 15 October and November 23 November. It was assumed that foliage leaching was low, especially for $\mathrm{N}, \mathrm{P}[26,32]$. This is not the case for $\mathrm{Mg}, \mathrm{K}$ and $\mathrm{Ca}$. However, we consider the results of these nutrients as relative on a comparative basis between sites subjected to the same influence of precipitation, and not as absolute.

After harvesting, all laminae areas were measured again after enclosure in a water-saturated atmosphere for 2 days. Specimens were dried and weighed after $24 \mathrm{~h}$ at $105^{\circ} \mathrm{C}$. Leaf areas of freshly harvested leaves were compared with those calculated from photographs to estimate the error between the measured and calculated surface areas $(4-5 \%)$. To estimate initial dry weights of the leaves collected after abscission, areas and weights were determined from measurements on freshly harvested leaves by a regression analysis between dry weight and area.

\subsection{Foliar analyses}

The three leaves from the same individual were pooled. Thus, we have three samples per species and per station. They were ground and digested in sulphuric acid-hydrogen peroxide-mercuric oxide for chemical analysis. Nitrogen was assessed using an automated method involving formation of a blue indophenol-like compound, phosphorus was measured by an automated phosphomolybdate blue method. Potassium was determined by flame emission spectrophotometry, calcium and magnesium by flame atomic absorption spectrophotometry [2].

\subsection{Data processing}

Foliar nutrient concentrations were calculated on a dry weight basis. Percentage change in leaf nutrient content during senescence (resorption $\mathrm{R}$ ) was calculated for each nutrient from concentrations $\left(\mathrm{mg} \cdot \mathrm{g}^{-1}\right)$ calculated per unit leaf mass and from percentage dry weight loss estimated from the regression

$$
\mathrm{R}=[(\mathrm{Ci} \times 100)-\mathrm{Cse} \times(100-\mathrm{P})] / \mathrm{Ci} \times 100
$$

where $\mathrm{Ci}$ is the nutrient concentration in green leaves, Cse the concentration in senescent leaves and $\mathrm{P}$ the weight loss estimated by regression between weight and area of green leaves (initial mass) and mass of senescent leaves.

Results of foliar and soil content and resorption were compared using a Student's $t$-test.

\section{Results}

\subsection{Soil nutrient content}

Concentrations of nutrients studied in flooded and unflooded areas vary according to the nutrient (table I). Organic carbon is higher in the unflooded forests. Nitrogen and potassium are also slightly higher in unflooded areas in spite of elimination of supply by floods. However, the $\mathrm{C} / \mathrm{N}$ ratio is similar in both types of site. On the contrary, total phosphorus shows a significantly lower value in the unflooded sites, whereas $\mathrm{Mg}$ and $\mathrm{Ca}$ do not change significantly $(P<0.05)$.

\subsection{Foliar studies}

\subsubsection{Shrinkage and dry weight decrease}

The regressions between dry weight and area on fresh leaves gave correlation values $(P<0.05)$ of $\mathrm{R}^{2}=0.70-0.75$ for Fraxinus, $\mathrm{R}^{2}=0.80$ for Ulmus and $\mathrm{R}^{2}=0.56-0.59$ for Clematis (table II). The lowest correlation between area and dry weight of Clematis could be due to the thinness and thus the fragility of the leaves, possibly resulting in nutrient leaching without area loss. 
Table I. Nutrient levels $\left(\mathrm{g} \cdot \mathrm{kg}^{-1}\right)$ in the top soil $(0-15 \mathrm{~cm}$ in depth) of the flooded and unflooded Rhine stands. Mean and standard deviation (std) for 12 samples, each consisting of ten subsamples. Probabilities $(P)$ represent differences between flooded and unflooded stands based on Student's $t$-test: - (not significant), $* P<0.1, * * P<0.05$.

\begin{tabular}{lccc}
\hline & Flooded stand & Unflooded stand & \\
\hline $\mathrm{C}$ & $42.1 \pm 24.0$ & $74.3 \pm 23.9$ & $* *$ \\
$\mathrm{~N}$ & $3.50 \pm 0.59$ & $3.98 \pm 0.39$ & $*$ \\
$\mathrm{C} / \mathrm{N}$ & $11.7 \pm 6.0$ & $17.7 \pm 5.9$ & \\
$\mathrm{P}$ & $0.038 \pm 0.016$ & $0.018 \pm 0.004$ & $* *$ \\
$\mathrm{~K}$ & $0.103 \pm 0.017$ & $0.131 \pm 0.060$ & - \\
$\mathrm{Mg}$ & $0.179 \pm 0.029$ & $0.158 \pm 0.019$ & - \\
$\mathrm{Ca}$ & $9.43 \pm 1.33$ & $7.34 \pm 0.11$ & $* *$ \\
\hline
\end{tabular}

The mean percentage shrinkage ranged from $10-12 \%$ in Clematis to 15-16\% in Fraxinus. Lamina dry weight loss of abscised leaves estimated by regression was about $25 \%$ for Clematis, $31 \%$ for Ulmus and between 28 and $32 \%$ for Fraxinus (table II).

\subsubsection{Foliar concentrations and resorption rates}

Flooded and unflooded forest produced senescent foliage that contained similar amounts of $\mathrm{N}$ but different amounts of $\mathrm{P}$ (figure 1). Unflooded forest has lower concentrations of $\mathrm{P}\left(0.84 \mathrm{mg} \cdot \mathrm{g}^{-1}\right)$ than has flooded forest $\left(1.27 \mathrm{mg} \cdot \mathrm{g}^{-1}\right)$.

There were significant differences in foliar $\mathrm{P}$ concentrations and amounts between individuals growing in flooded and unflooded sites. This element was around

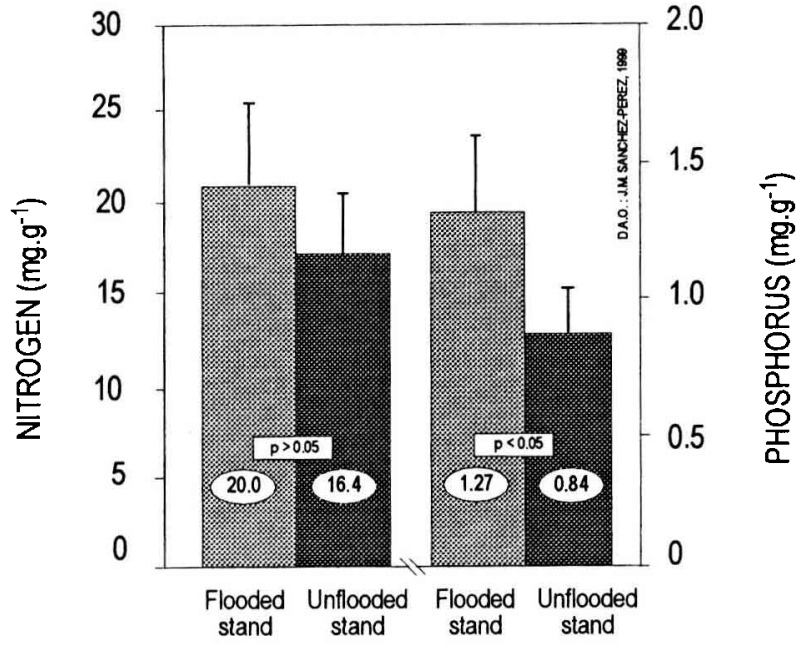

Figure 1. Mean concentration $\left(\mathrm{mg} \cdot \mathrm{g}^{-1}\right)$ of nitrogen $(\mathrm{N})$ and phosphorus $(\mathrm{P})$ in the senescent leaves of the three deciduous woody species in flooded and unflooded forests. Error bars represent $1 \mathrm{SE}$, and probabilities $(P)$ represent differences between flooded and unflooded stands based on Student's $t$-test.

$30 \%$ lower in unflooded sites for the three test species summer and senescent leaves. But there are no significant differences between the two types of site for the other nutrients $(\mathrm{N}, \mathrm{K}, \mathrm{Mg}, \mathrm{Ca})$, except for $\mathrm{N}$ in summer leaves of Fraxinus and Clematis $(P=0.09$ ) (table III). Clematis shows the highest difference between the two types of site with respect to summer leaf content (45\% for $\mathrm{N}$ and $32 \%$ for $\mathrm{P}$ ).

Table II. Mean percentage loss in lamina area and dry weight. Loss of dry weight was calculated on a regression basis. Regression equations are as follows: Fraxinus flooded sites $(\mathrm{y}=4.481 \mathrm{x}-24.561)$, Fraxinus unflooded sites $(\mathrm{y}=3.649 \mathrm{x}-1.451)$, Ulmus flooded sites $(y=2.139 x-0.041)$, Ulmus unflooded sites $(y=5.141-34.123)$, Clematis flooded sites $(y=4.236 x-1.450)$, Clematis unflooded sites $(y=6.123 x-21.450)$; $y$ represents dry weight and $x$ the lamina area (mature leaves).

\begin{tabular}{lcccc}
\hline & $\mathrm{N}$ & $\begin{array}{c}\text { Mean percentage } \\
\text { loss in lamina area }\end{array}$ & $\begin{array}{c}\text { Mean percentage } \\
\text { loss in dry weight }\end{array}$ \\
\hline $\begin{array}{l}\text { Fraxinus excelsior } \\
\text { - Flooded sites }\end{array}$ & 24 & $15.1 \pm 9.9$ & $32.5 \pm 15.3$ & $\mathrm{R}^{2}$ \\
$\begin{array}{l}\text { - Unflooded sites } \\
\text { Ulmus minor }\end{array}$ & 22 & $15.9 \pm 15.0$ & $28.2 \pm 1.7$ & 0.75 \\
- Flooded sites & 25 & $11.5 \pm 6.6$ & $30.8 \pm 10.8$ & 0.70 \\
$\begin{array}{l}\text { - Unflooded sites } \\
\text { Clematis vitalba }\end{array}$ & 24 & $12.9 \pm 5.2$ & $30.8 \pm 10.0$ & 0.80 \\
- Flooded sites & 23 & $12.0 \pm 14.0$ & $26.2 \pm 20.0$ & 0.80 \\
- Unflooded sites & 25 & $10.4 \pm 8.9$ & $24.6 \pm 20.0$ & 0.56 \\
\hline
\end{tabular}


Table III. Mean values of contents on a dry weight basis $\left(\mathrm{mg} \cdot \mathrm{g}^{-1}\right.$ ) of major nutrients in mature and senescent leaves of the test species. The level of significance of differences in content between species growing in flooded and unflooded sites was determined by a Student's $t$-test: - (not significant), ${ }^{*} P<0.1,{ }^{* *} P<0.05$.

\begin{tabular}{|c|c|c|c|c|c|}
\hline & $\mathrm{N}$ & $\mathrm{P}$ & $\mathrm{K}$ & $\mathrm{Mg}$ & $\mathrm{Ca}$ \\
\hline \multicolumn{6}{|l|}{ Fraxinus excelsior } \\
\hline \multicolumn{6}{|l|}{ Summer leaves } \\
\hline - Unflooded sites & $24.0 \pm 5.3$ & $1.17 \pm 0.15$ & $12.3 \pm 2.3$ & $7.1 \pm 1.2$ & $39.8 \pm 4.4$ \\
\hline Significance & * & $* *$ & - & - & - \\
\hline \multicolumn{6}{|l|}{ Autum leaves } \\
\hline Significance & $*$ & $* *$ & - & - & - \\
\hline \multicolumn{6}{|l|}{ Ulmus minor } \\
\hline \multicolumn{6}{|l|}{ Summer leaves } \\
\hline - Flooded sites & $36.8 \pm 9.5$ & $1.97 \pm 0.55$ & $20.0 \pm 2.9$ & $3.2 \pm 1.0$ & $23.3 \pm 1.4$ \\
\hline - Unflooded sites & $26.6 \pm 5.7$ & $1.47 \pm 0.06$ & $18.4 \pm 6.9$ & $3.0 \pm 1.0$ & $24.0 \pm 2.6$ \\
\hline Significance & $*$ & - & - & - & - \\
\hline \multicolumn{6}{|l|}{ Autum leaves } \\
\hline \multicolumn{6}{|l|}{ Clematis vitalba } \\
\hline \multicolumn{6}{|l|}{ Summer leaves } \\
\hline - Flooded sites & $42.8 \pm 14.2$ & $2.10 \pm 0.61$ & $19.2 \pm 3.5$ & $4.2 \pm 1.5$ & $42.2 \pm 4.5$ \\
\hline - Unflooded sites & $23.4 \pm 4.2$ & $1.43 \pm 0.31$ & $23.5 \pm 3.6$ & $2.4 \pm 0.7$ & $39.3 \pm 5.1$ \\
\hline Significance & $*$ & $*$ & - & $*$ & - \\
\hline \multicolumn{6}{|l|}{ Autum leaves } \\
\hline - Flooded sites & $17.6 \pm 3.4$ & $1.16 \pm 0.30$ & $9.3 \pm 2.2$ & $3.1 \pm 0.9$ & $38.1 \pm 5.3$ \\
\hline - Unflooded sites & $13.4 \pm 4.0$ & $0.83 \pm 0.09$ & $12.2 \pm 4.8$ & $2.0 \pm 0.9$ & $39.9 \pm 5.3$ \\
\hline Significance & $*$ & $*$ & - & $*$ & - \\
\hline
\end{tabular}

Resorption occurred in flooded and unflooded stands and varied with the species (figure 2). Nutrient resorption was 40 and $70 \%$ for $\mathrm{N}, \mathrm{P}$ and $\mathrm{K}$ in the three test species and lower for $\mathrm{Ca}$ and $\mathrm{Mg}(0-45 \%)$, Ca showing the lowest resorption. It did not vary significantly after elimination of flooding. However, we observed a few trends, i.e. a decrease in $\mathrm{N}$ resorption, especially for Fraxinus in the unflooded sites: thus we measured a resorption of $59.4 \%$ in the flooded sites against only $45.2 \%$ in the unflooded ones, corresponding to a reduction in resorption of $23.8 \%$ in unflooded sites compared to flooded sites. On the other hand, the resorption of $\mathrm{K}$ was higher in the unflooded site than in the flooded one in Fraxinus and $\mathrm{Ca}$ was more resorbed in Clematis in the flooded site than in the unflooded one.

\section{Discussion}

\subsection{Nutrient soil availability}

The soil content of Rhine alluvial sites was similar to those measured in the south-Moravian floodplain [19].
The suppression of floods leads to a reduction in soluble phosphorus input, which largely explains the lower soil content measured in the unflooded site. In contrast, there is no significant difference in $\mathrm{N}, \mathrm{Mg}$ and $\mathrm{Ca}$ soil content.

\subsubsection{Nitrogen}

Nitrogen concentrations were relatively high (more than $3 \mathrm{~g} \cdot \mathrm{kg}^{-1}$ ) as compared with selected soils collected in the United States $[8,30]$. The low $\mathrm{C} / \mathrm{N}$ ratio (around $15)$ in both sites, flooded and unflooded, exhibits favourable conditions for mineral nutrition of trees.

The source of nitrate is both external as in the case of transport by flood waters $\left(20.4 \mathrm{~kg} \cdot \mathrm{ha}^{-1}[41]\right)$ and precipitation (atmospheric inputs: $13.7 \mathrm{~kg} \cdot \mathrm{ha}^{-1}$ ) and internal as a result of an active biotic cycle. In fact all the sites of the alluvial plain are highly nitrifying: nitrate nitrogen represents $85 \%$ of mineralizable nitrogen and the most efficient site produces about $660 \mathrm{mg}$ mineral nitrogen per $100 \mathrm{~g}$ organic matter per year [36]. When the water 

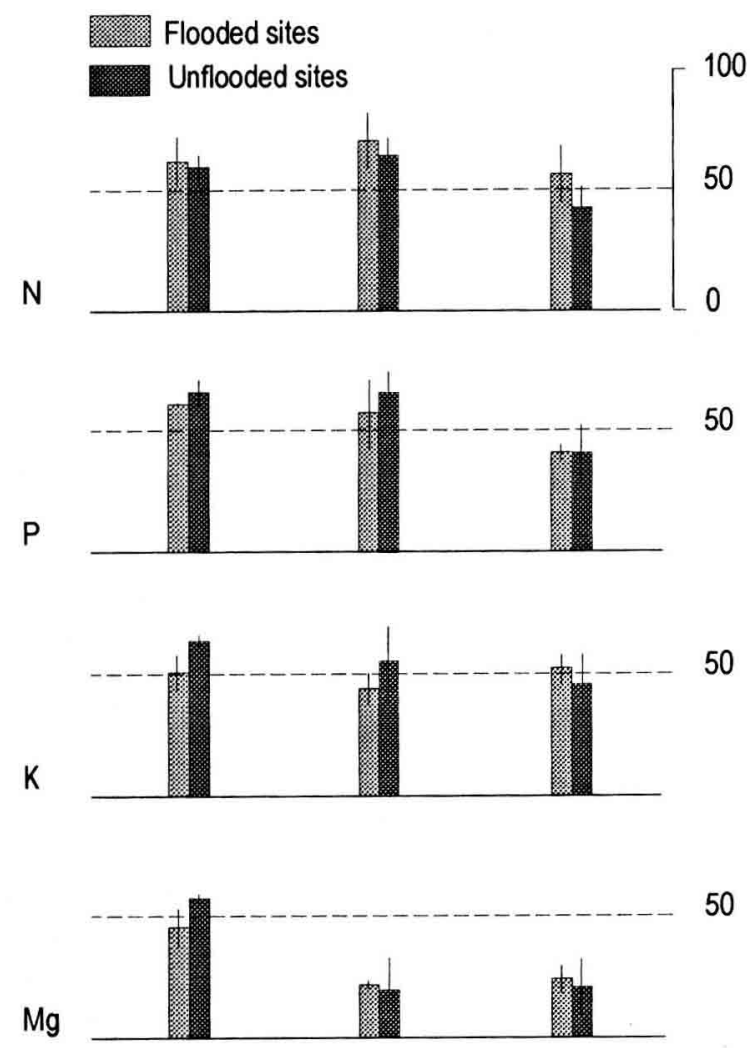

50

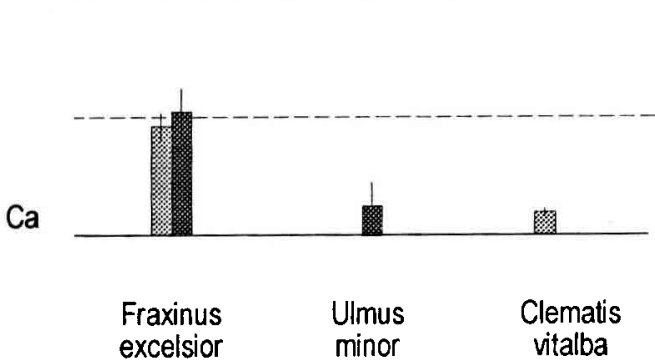

Figure 2. Percentage decreases (resorption \%) in nutrient contents in leaves of the three test species before abscission of deciduous woody species in flooded and unflooded forests. Error bars represent $\pm 1 \mathrm{SE}$.

table drops below ground level, aeration of soil stimulates nitrification and increases soil nitrate concentrations at sites both behind and in front of the dykes. We measured up to $17 \mathrm{mg} \cdot \mathrm{L}^{-1} \mathrm{~N}-\mathrm{NO}_{3}{ }^{-}$in groundwater after a flood when water is infiltrating [33] and $29 \mathrm{mg} \cdot \mathrm{L}^{-1} \mathrm{~N}$ $\mathrm{NO}_{3}{ }^{-}$in the soil solution of a sandy-silty terrace. The active biotic nitrogen processing is favoured both by the rich nitrifying bacterial population in the floodplains $[9$, 12] and fluctuations in water level. However, in the flooded stand where the soil nitrogen content is slightly lower than that at the unflooded one, nitrification is probably compensated by denitrification resulting from saturation of the soil, which leads to a low level of oxygen. This last process no longer occurs in the unflooded stand.

\subsubsection{Phosphorus}

Sediments represent a large proportion of the ecosystem phosphorus capital although only a small proportion may be in a form available for plants depending on soil $\mathrm{pH}$, redox potentiel and temperature [6, 15, 31]. High soil phosphorus content in the flooded islands $\left(0.038 \mathrm{~g} \cdot \mathrm{kg}^{-1}\right)$ could be attributed to flood deposits (estimated to $0.124 \mathrm{~g} \cdot \mathrm{kg}^{-1}$ [34]). On the other hand, the alternating processes of $P$ solubilization/precipitation in the flooded calcareous soils can provide available phophorus retained on active lime, a part of which is extracted by oxalate. However, good retention capacity of the calcareous sediments and lack of leakage from the ecosystem is confirmed by low $\mathrm{P}$ level in groundwater [33]. The measured available phosphorus concentrations were about $50 \%$ lower behind the dykes because there was no process of autogenesis similar to that of the nitrogen cycle, which could compensate loss of regular $P$ inputs from floodwaters.

\subsubsection{Calcium}

Calcium is a very abundant element $\left(9.43 \mathrm{~g} \cdot \mathrm{kg}^{-1}\right)$ in all flooded Rhine soils. Fluctuations of water level in flooded soils contribute to a change in $\mathrm{Ca}$ carbonate to active lime, as evidenced by readier extraction by ammonium acetate, which can increase the $\mathrm{Ca}$ soil content. Calcium concentration decreases slowly after the cessation of geomorphogenesis and the onset of pedogenesis owing to suppression of floods, which explains the lower $\mathrm{Ca}$ value in unflooded areas $(-22 \%)$. In these sites, we observe on the soil surface a change of humus from a hydromull to a mull moder (or even to a xeromoder owing to the decrease in water level) since organic matter accumulates as result of it not being transformed [3] and the top soil composition evolves to decarbonatation.

\subsection{Mineral nutrition versus fertility of soil}

In the unflooded sites, nitrogen and phosphorus concentrations in mature leaves of deciduous trees are of the same order as those indicated by Aerts [1] $\left(22 \mathrm{mg} \cdot \mathrm{g}^{-1} \mathrm{~N}\right.$, $1.6 \mathrm{mg} \cdot \mathrm{g}^{-1} \mathrm{P}$ ), but those measured in the flooded sites are significantly higher, except for Fraxinus. The difference in the nutrient content of mature leaves between both 
sites suggests a particular contribution of flooding. First, this could be linked to direct nutrient input from floodwaters. Second, the regular alternation between flooding and dry periods favours nutrient release from soil organic matter, allowing a rapid uptake by species. These results do not reveal the direct influence of site fertility, since for $\mathrm{N}$ and $\mathrm{K}$, for example, there is a negative relation between soil content and mature leaf content, which is in contradiction with results of a study on a Mediterranean Quercus ilex forest [32] These authors attribute higher $\mathrm{N}$ and $\mathrm{P}$ concentrations in relation to higher soil content to a higher temperature and water availability which enhances microbial activity. In the flooded sites, the water and nutrient availability was improved. In fact flooding favours production of biomass and nutrient utilization of seedlings. However, the response of plants to flooding in terms of nutrient concentration in different parts of the plant changes greatly according to the nutrient [23]. Phosphates are not easily available to plants because of their low solubility in calcareous waters and their adsorption on soil colloids. In flooded sites, however, plants benefit from inputs of soluble phosphate by floods and temporary release of adsorbed phosphates during and after the flooding through reduction of Fe III to Fe II [29] which is readily mobile and available for plant uptake [25].

The average $\mathrm{N}$ and $\mathrm{P}$ values of the senescent leaves of the three species are higher than those of around $9.3 \mathrm{mg} \cdot \mathrm{g}^{-1} \mathrm{~N}$ and $0.6 \mathrm{mg} \cdot \mathrm{g}^{-1} \mathrm{P}$ for deciduous trees found by Killingbeck [17] from data collected at numerous locations in the USA. Rates of nutrient return from leaves to the forest floor in southern hardwood forests of USA (Illinois, North Carolina, Florida) were found to be higher in alluvial ecosystems than those for upland ecosystems, which suggests that fluvial processes are important in maintaining the high fertility of riparian forests [7]. However, there is no significant difference between the two types of site, except for $\mathrm{P}$ in all species. Woody species in unflooded forest seem to be more proficient at reducing $\mathrm{P}$ in their senescent leaves than are species in flooded forest as demonstrated by Ulmus in which the concentrations in summer leaves are not significantly different between the two sites, but those of senescent leaves are (table III). This may be explained by the fact that less $P$ is available to the trees in unflooded areas than in flooded areas as a consequence of the elimination of the supply by floods (table I). However, $\mathrm{P}$ resorption is not significantly different in both types of sites.

\subsection{Parameters controlling nutrient resorption}

The data for resorption of $\mathrm{N}$ and $\mathrm{P}$ obtained in the alluvial sites are in accordance with those collected in the literature by Aerts [1] which are around $50 \%$ for deciduous trees. On the other hand, no significant differences in resorption appear for the three species between the two sites. Given the significant differences observed for $\mathrm{N}, \mathrm{P}$ and $\mathrm{K}$ in the mature leaves between the two types of sites, we tried to correlate content in mature leaves of one given element and resorption of this element (figure 3). There is a positive correlation $\left(\mathrm{R}^{2}=0.39, P<0.05\right)$ for nitrogen and no correlation for the other nutrients. The trend towards a decrease in $\mathrm{N}$ resorption with decreasing concentration of this element in the leaves of Fraxinus and Ulmus in unflooded areas is in contradiction to a high resorption in relatively nutrient-poor soil $[28,35]$ and in agreement with studies showing high resorption on nutrient-rich soil. Comparable results have been obtained in other European mull sites of variable fertility, in upland oak communities of Belgium [13] and beech forests of southern Sweden [39]. Our results confirm that there is no direct effect of soil fertility on resorption [1], as already shown for nitrogen uptake. The difference in resorption could be attributed to the fluctuations in water level and consequently to the soil moisture availability which has been stressed as an important determinant of nutrient resorption efficiency by Aerts [1]: thus a higher resorption value was observed at sites with higher water availability [32]. However, the difference in soil humidity between the two types of sites are not very great (humidity around $45-50 \%$ ). The high fluctuations of water level could act as a stress on $\mathrm{N}$ resorption in relation to alternation of nitrification and denitrification periods, this last process occurring frequently during the growing season and thus limiting the $\mathrm{N}$ availability. This flooding stress could lead to a higher resorption of nitrogen.

An unexpected result was that there is no difference for $\mathrm{P}$ resorption between flooded and unflooded sites in the three test species, in spite of a significant decrease in $\mathrm{P}$ concentrations in the summer and autumn leaves of the unflooded sites and significant differences of $P$ level in soils of flooded and unflooded sites. For Fraxinus, this result is in contradiction to those of Weiss et al. [42] and Weiss and Trémolières [43], who showed higher differences in concentrations between summer leaves and senescent leaves in sites poorer in phosphorus (unflooded sites). However, the methodology used in the two studies is quite different as was the objective. Weiss et al. [42] measured concentrations of phosphorus in leaves before abscission and in leaf litter, as is commonly measured by authors in resorption studies. In the present study, our results suggest good nutrient supply behind the dykes, except perhaps for Fraxinus, which could be related to an increase in fungal mycorrhizal populations which compensates the loss of soluble $P$ inputs $[10,14$, 21]. Fraxinus is a particular case when this species 

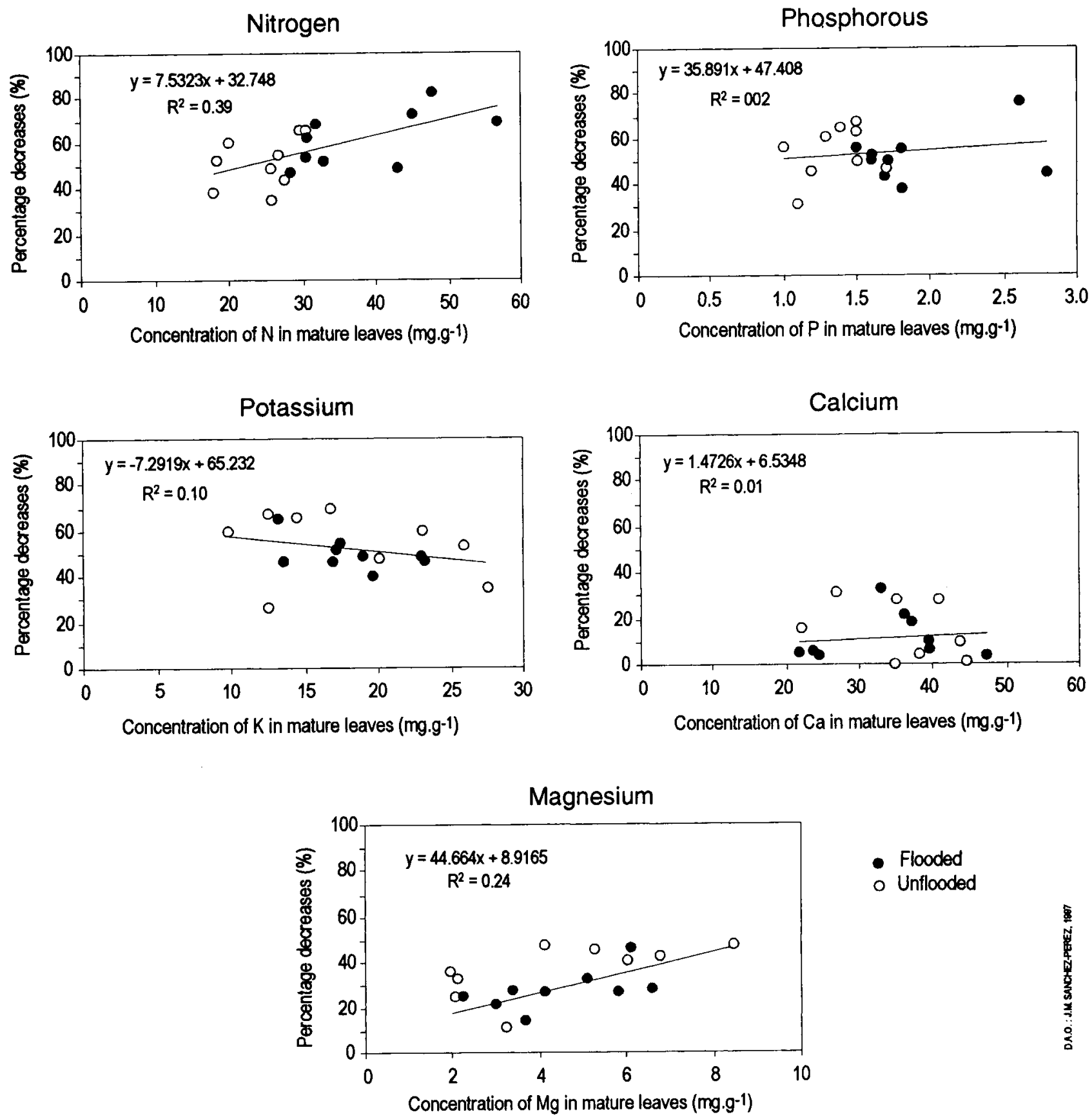

- Flooded

o Unflooded

Figure 3. Relation between resorption (\% decrease) and nutrient content in mature leaves of the three species in flooded and unflooded sites.

shows a very low foliar concentration by comparison with that measured for example in the south Moravian floodplain forests $\left(3.4 \mathrm{mg} \cdot \mathrm{g}^{-1}\right)$ [18]. However, the leaves were collected in August and Weiss et al. [42] have shown that the foliar concentrations in August were two to three times lower than the concentrations in May or even in July, in both flooded and unflooded forests. 
The similar foliar contents and resorption rates of $\mathrm{K}$, $\mathrm{Mg}$ and $\mathrm{Ca}$ for Ulmus and Clematis at all sites suggest that the amounts of these elements are sufficient in the unflooded sites, which is due to the geochemistry of the Rhine alluvial deposits. Fraxinus exhibited a trend to store $\mathrm{K}$ in perennial organs in the unflooded sites which is visible in the lower $\mathrm{K}$ content in senescent leaves behind the dykes, whereas the summer leaf content is not different in the two sites. This species clearly has high $\mathrm{K}$ requirements as has also been recorded in the south Moravian floodplain forests [18].

The present study has shown that the foliar $\mathbf{P}$ concentrations of leaves are directly linked to flood and fluctuations in groundwater level. But this relationship is less clear for $\mathrm{N}, \mathrm{K}, \mathrm{Mg}$ and $\mathrm{Ca}$. Given the good availability of nutrients even in unflooded sites owing to compensation factors (e.g. for phosphorus) or high nutrient content in soil $(\mathrm{Ca}$ and $\mathrm{Mg})$, resorption which was often interpreted as an economy process in the mineral nutrition of plants occurs largely in the alluvial ecosystems and does not change after suppression of floods, in spite of a decrease in nutrient supply and low variations in water level. The higher $\mathrm{N}$ resorption in the flooded sites could be interpreted as an effect of flood stress, which can limit the bioavailability of nitrogen.

Acknowledgement: We are indebted to Mrs Corrigé for analyses of the leaves in the Inra laboratory (Institut national de recherche agronomique) at Colmar.

\section{References}

[1] Aerts R., Nutrient resorption from senescent leaves of perennials: are there general patterns?, J. Ecol. 84 (1996) 597-608.

[2] APHA, Standard Methods for the Examination of Water and Wastewater, 16th ed., American Public Health Association, Washington, 1985.

[3] Badre B., Recyclage de la matière organique et dynamique des éléments minéraux en milieu forestier alluvial. Influence du degré d'inondabilité, Ph.D. thesis, Strasbourg University, France, 1996.

[4] Birk E.M., Vitousek P.M., Nitrogen availability and nitrogen use efficiency in Loblolly pine stands, Ecology 67 (1986) 69-79.

[5] Boerner R.E.J., Foliar nutrient dynamics and nutrient use efficiency of four deciduous tree species in relation to site fertility, J. Appl. Ecol. 21 (1984) 1029-1040.

[6] Boers P.C.M., van Hese O., Phosphorus release from the peaty sediments of the Loosdrecht lakes (Netherlands), Water Res. 22 (1988) 355-363.

[7] Brinson M.M., Riverine forests, in: Lugo A., Brinson M., Brown S. (Eds.), Ecosystems of the World, 15: The Forested Wetlands, Elsevier, Amsterdam, 1990, pp. 87-141.
[8] Brinson M.M., Bradshaw H.D., Kane E.S., Nutrient assimilative capacity of an alluvial floodplain swamp, J. Appl. Ecol. 21 (1984) 1041-1057.

[9] Carbiener R., Un exemple de type forestier exceptionnel pour l'Europe occidentale: la forêt du lit mineur du Rhin au niveau du fossé rhénan (Fraxino-Ulmetum). Intérêt écologique et biogéographique. Comparaison à d'autres forêts thermophiles, Vegetatio 20 (1970) 97-108.

[10] Carbiener R., Der Beitrag der Hutpilze fur soziologischen und synökologischen Gliederung von Auen und Feuchtwäldern, ein Beispiel aus der Oberrheinebene, in: Cramer J. (Ed.), Berichte der internationalen Symposien der internationalen Vereinigung für Vegetationskunde "Syntaxonomie", Vaduz, Germany, 1981, pp. 497-531.

[1 1] Demars B.G., Boerner R.E.G., Foliar nutrient dynamics and resorption in naturalized Lonicera mackii (Caprifoliaceae) populations in Ohio, USA, Am. J. Bot. 84 (1997) 112-117.

[12] Donaldson J.M., Henderson G.S., Nitrification potential of secondary succession upland forests, Soil Sci. Soc. Am. J. 54 (1990) 898-902.

[13] Duvigneaud P., Denaeyer-deSmet S., Cycle des éléments biogènes dans les écosystèmes en Europe (principalement caducifoliés), in: International Symposium « Productivité des écosystèmes forestiers », Brussels, Belgium, 1971.

[14] Gianinazzi-Pearson V., Gianinazzi S., The fungal community, its organization and role in the ecosystem, Mycology series 2 (1981) 637-652.

[15] Golterman H.L., de Groot C.J., Nouvelles connaissances des formes du phosphate: conséquences sur le cycle du phosphate dans les sédiments des eaux douces peu profondes, Ann. Limnol. 30 (1994) 221-232.

[16] Helmisaari H., Nutrient resorption in three Pinus sylvestris stands, For. Ecol. Manag. 51 (1992) 347-367.

[17] Killingbeck K.T., Nutrients in senescent leaves: keys to the search for potential resorption and resorption proficiency, Ecology 77 (1996) 1716-1727.

[18] Klimo E., Cycling of mineral nutrients, in: Penka M., Vyskot M., Klimo E., Vasicek F. (Eds.), Floodplain Forest Ecosystem, I. Before Water Management Measures, Elsevier, Amsterdam, The Netherlands, 1985, pp. 425-459.

[19] Klimo E., Prax A., Soil conditions, in: Penka M., Vyskot M., Klimo E., Vasicek F. (Eds.), Floodplain Forest Ecosystem, I. Before Water Management Measures, Elsevier, Amsterdam, The Netherlands, 1985, pp. 61-78.

[20] Klinge K., Foliar nutrient levels of native tree species from Central Amazonia. Inundation forests, Amazoniana VI(1) (1985) 19-45.

[21] Le Tacon F., Les mycorhizes: une coopération entre plantes et champignons, La recherche 166 (1985) 624-632.

[22] Lugo A., Brinson M., Brown S., Ecosystems of the World, 15: The Forested Wetlands, Elsevier, Amsterdam, The Netherlands, 1990.

[23] McKevlin M.R., Hook D.D., McKee Jr, Growth and nutrient use efficiency of water tupelo seedlings in flooded and well-drained soil, Tree Physiol. 15 (1995) 753-758. 
[24] Mitsch W.J., Dorge D.L., Wiemhoff J.R., Ecosystem dynamics and a phosphorus budget in a alluvial cypress swamp in southern Illinois, Ecology 60 (1979) 1116-1124.

[25] Moorhead K.K., McArthur J.V., Spatial and temporal patterns of nutrient concentrations in foliage of riparian species, Ann. Midl. Nat. 136 (1996) 29-41.

[26] Mougougou A., Trémolières M., Sanchez-Perez J.M., Nobelis P., Réalité de l'excrétion foliaire en milieu forestier alluvial chez deux espèces ligneuses de la sous-strate arborescente, C. R. Acad. Sci. Paris, Sciences de la Vie 321 (1998) 915-922.

[27] Nambiar E.K.S., Fife D.N., Growth and nutrient translocation in needles of Radiata pine in relation to nitrogen supply, Ann. Bot. 60 (1987) 147-156.

[28] Odum E.P., The strategy of ecosystem development, Science 164 (1969) 262-270.

[29] Patrick W.H., Mahapatra I.C., Transformation and availability to rice of nitrogen and phosphorous in waterlogged soils, Adv. Agron. 20 (1968) 323-359.

[30] Reddy K.R., Patrick W.H., Phillips R.E., The role of nitrate diffusion in determining the order and rate of denitrification in flooded soil: I. Soil experimentation, Soil Sci. Soc. Am. J. 42 (1978) 268-272.

[31] Redshaw C.J., Mason C.F., Hayes C.R., Roberts R.D., Factors influencing phosphate exchange across the sedimentwater interface of eutrophic reservoirs, Hydrobiologia 192 (1990) 233-245.

[32] Sabaté S., Sala A., Garcia C.A., Nutrient content in Quercus ilex canopies: seasonal and spatial variation within a catchment, Plant Soil 168-169 (1995) 297-304.

[33] Sánchez-Pérez J.M., Trémolières M., Schnitzler A., Carbiener R., Evolution de la qualité physico-chimique des eaux de la frange superficielle de la nappe phréatique en fonction du cycle saisonnier et des stades de succession des forêts alluviales rhénanes, Acta Oecol. 12 (5) (1991) 581-601.

[34] Sánchez-Pérez J.M., Trémolières M., Schnitzler A., Badre B., Carbiener R., Nutrient content in alluvial soils sub- mitted to flooding in the Rhine alluvial deciduous forest, Acta Oecol. 14 (3) (1993) 3-17.

[35] Schlesinger W.H., Biogeochemical limits on two levels of plant community organization in the cypress forest of Okefenokee Swamp, thesis, Cornell University, Ithaca, New York, 1976

[36] Schnitzler A., Typologie phytosociologique, écologie et dynamique des forêts alluviales du complexe géomorphologique ello-rhénan (plaine rhénane d'Alsace), Ph.D. thesis, Strasbourg University, France, 1988.

[37] Schnitzler A., Succession and zonation in gallery forest, J. Veg. Sci. 6 (1995) 479-486.

[38] Son Y., Gower S.T., Aboveground nitrogen and phosphorus use by five plantation -grown trees with different leaf longevities, Biogeochemistry 14 (1991) 167-191.

[39] Staaf H., Plant nutrient changes in beech leaves during senescence as influenced by site characteristics, Acta Oecol./Oecol. Plant. 3 (1982) 161-170.

[40] Trémolières M., Carbiener D., Carbiener R., Eglin I., Robach F., Sánchez-Pérez J.M., Schnitzler A., Weiss D., Zones inondables, végétation et qualité de l'eau en milieu alluvial rhénan: l'île de Rhinau, un site de recherches intégrées, Bull. Ecol. $223-4$ (1991) 317-336.

[41] Trémolières M., Sánchez-Pérez J.M., Schnitzler A., Schmitt D., Impact of river management history on the community structure, species composition and nutrient status in the Rhine alluvial hardwood forest, Plant Ecol. 135 (1998) 59-78.

[42] Weiss D., Trémolières M., Carbiener R., Biodisponibilité comparée du phosphore en fonction des substrats et de la fréquence des inondations dans trois forêts alluviales Rhénanes de la plaine d'Alsace, C. R. Acad. Sci., Paris, Série III 313 (1991) 245-251.

[43] Weiss D., Trémolières M., Impact des inondations sur la biodisponibilité du phosphore dans deux forêts alluviales de la plaine d'Alsace (France), C. R. Acad. Sci. Paris, série III 316 (1993) 211-218. 